The BDJ News section accepts items that include general news, latest research and diary events that interest our readers. Press releases or articles may be edited, and should include a colour photograph if possible. Please direct your correspondence to the News Editor, Arveen Bajaj at the BDJ, 64 Wimpole Street WIG 8YS or by email to bdj@bda.org

\section{New GDC member elected}

Dentists in Wales have elected Mary Dodd as the new member of the General Dental Council. She fills the vacancy left by Trevor Griffiths, who stepped down as the GDC member for Wales earlier this year for health reasons.

Mary Dodd will serve on the GDC until the 9 April 2008, when the five-year term of the current Council comes to an end. Thirty eight per cent of the electorate (dentists with a registered address in Wales) voted. The Council has 29 members, 15 dentists (elected by other dentists), four professionals complementary to dentistry (elected by other PCDs) and ten members of the public (appointed by the Queen).

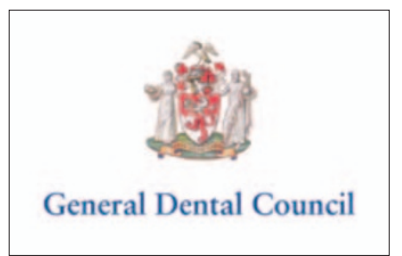

\section{High tech education}

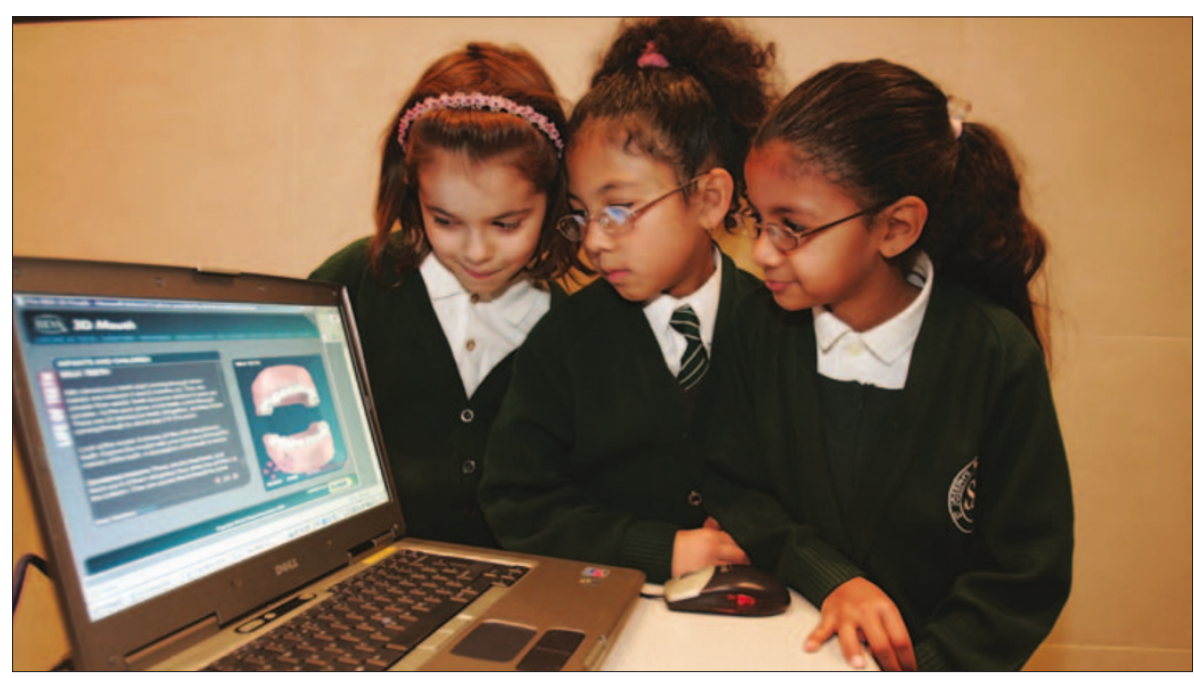

Children from St. Joseph's Roman Catholic Primary School recently helped launch the BDA's new website www.3dmouth.org at the British Museum in London. The website, which is supported by Wrigley's Orbit, uses cutting edge technology to help teach children at Key Stage 2 of the National Curriculum learn about their teeth and how to look after them throughout their lives. As each page in the website loads, users are treated to interesting facts, including the ability of giraffes to lick their own ears with their 23inch tongues and that, despite having a mouth the size of a pinhead, a snail has around 25,000 teeth. It is also anticipated that dentists will use the site in their practices to help explain treatments to their patients.

\title{
New Editor-in-Chief appointed to BDJ
}

The British Dental Association has appointed Stephen Hancocks as the new Editor-in-Chief of the British Dental Journal.

He will take over from Dr Mike Grace who is leaving as editor of the $B D J$ after twelve years.

Dr Hancocks OBE, an established figure in dental publishing for the last 20 years, will step into the newly created role and has responsibility for developing the scientific and academic profile of the $B D J$ which already enjoys a high global reputation.

In addition, the Editor-in-Chief will take on a wider editorial role involving other BDA publications including Vital, a quarterly publication for professionals complementary to dentistry, membership magazine, BDA News and the termly magazine for dental students, Launchpad. Since 1997, Dr Hancocks has served as the
$B D J$ s commissioning editor. A qualified dentist, he writes and lectures extensively on dentistry and is also the editor of the FDI's International Dental Journal.

Announcing the appointment, Chair of the BDA's Executive Board, Dr John Renshaw said, "The British Dental Journal plays a crucial role in promoting the science of dentistry, making a major contribution to both research and general practice. I am delighted Stephen Hancocks is taking on this role which will build upon the formidable achievements of Mike Grace."

Stephen Hancocks said, "I am truly delighted and humbled by the opportunity to take up this new position at such an important time in the development of the $B D J$ and the other BDA publications. I look forward to the challenge and to building on the fine work of my illustrious predecessors."

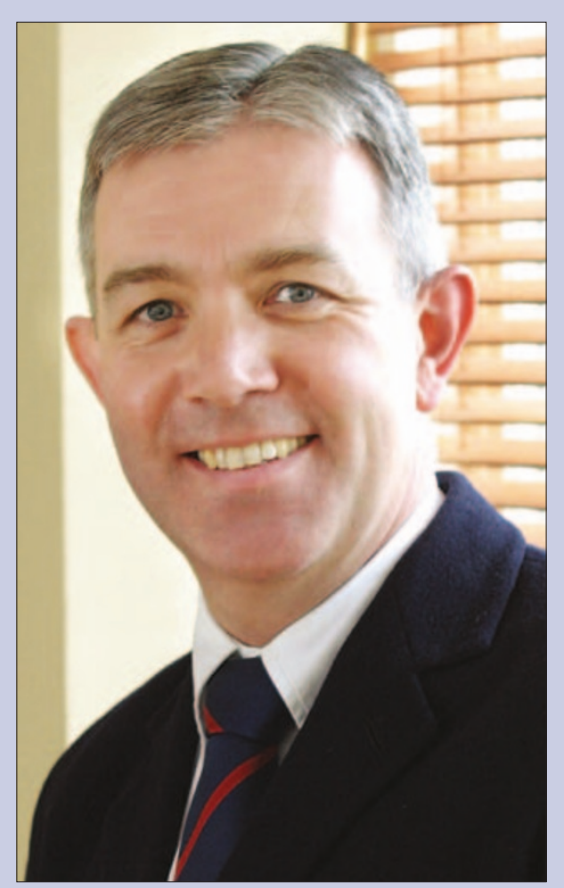

Dr Stephen Hancocks OBE 


\section{DIARY}

\section{January 2005}

OSAP 4th Annual Intermediate-Level Infection Control and Occupational Safety and Health Course

Date: 24-27.01.04

Venue: Hyatt Regency Atlanta, Georgia Tel: 800-298-OSAP (6727)

www.osap.org.

International Dental Foundation 54th International Alpine Dental Conference

Date: 29.01.05-05.02.05

Venue: Hotel Annapurna, Courcheval 1850, France

Contact: Robert Wallace

Tel: +44 (0) 2072350788

Fax: +44 (0) 2072350767

Email: idf@idfdentalconference.com www.idfdentalconference.com

\section{March 2005}

83rd General Session \& Exhibition of the IADR, 34th Annual Meeting of the AADR, 29th Annual Meeting of the CADR

Date: 9-12.03.05

Venue: Baltimore Convention Centre www.dentalresearch.org

\section{April 2005}

Academy of Laser Dentistry Source 2005: Lasers in Dentistry

Date: 6-9.04.05

Venue: New Orleans Marriott Hotel, New

Orleans, Louisiana, USA

Tel: 1-877-527-3776

Email: memberservices@

laserdentistry.org

www.source2005.org

\section{Two new Vice-Deans}

The Faculty of General Dental Practitioners (UK) has announced the appointment of its new Vice-Deans, Dr Clive Gibson and Dr Nikolaus Palmer.

After graduating from the University of London, Dr Gibson spent five years as a dental surgeon in the Royal Air Force before building up a dental practice in Wolverhampton.

Alongside a significant commitment to the NHS, he has developed a special interest in implants and advanced restorative dentistry.

He is particularly active in postgraduate dental education and ran a vocational dental training scheme before becoming Deputy Director of Postgraduate Dental Education for the West Midlands Deanery.

He is currently studying for a Masters in Medical Education.

Dr Palmer trained in Liverpool, where he is now an associate general dental practitioner with a special interest in orthodontics in a mainly NHS practice.

He is very active in the north-west, where he is a regional specialty tutor for the Mersey Deanery and part-time lecturer in clinical dental sciences at the University of Liverpool.

He completed his $\mathrm{PhD}$ on antibiotic prescribing in general dental practice and has published numerous papers on the subject.

He is a member of a number of committees, his most recent involvement being on the Department of Health's national development group for dentists

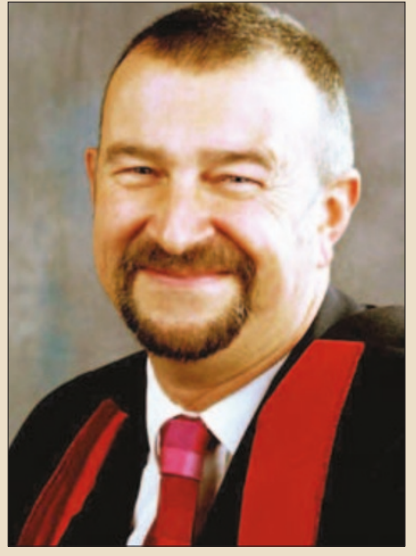
Dr Clive Gibson

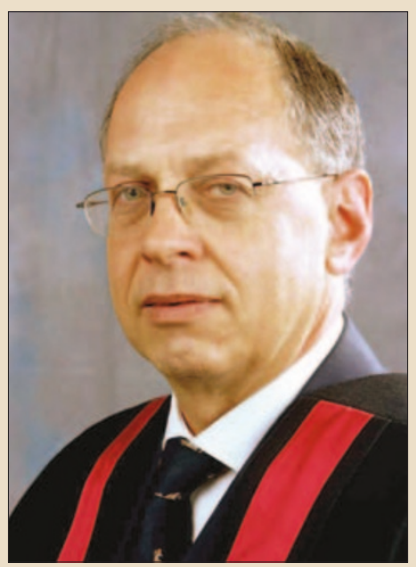

Dr Nikolaus Palmer with special interests. 


\section{Pilot trip a success}

A small team of volunteer UK dental professionals has recently returned from a visit to Tanzania in November as part of the pilot visit of the Dentaid/Bridge2Aid Dental Volunteer Programme (DVP).

The team's role was to provide one-on-one training for Rural Clinical Officers (RCOs) in basic diagnosis, local anaesthesia and extractions.

RCOs are at the front line of health care provision to the rural communities in Tanzania, where

over $80 \%$ of the population lives. The team gather to teach from an interesting case According to the charity, access

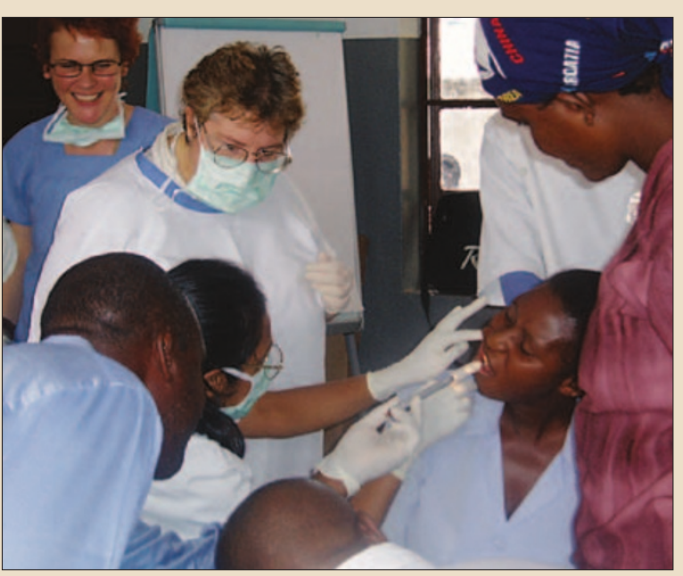
to a dentist to treat even simple problems is severely limited by geographical distance and lack of resources, and the training of RCOs is a significant factor that can improve the provision of basic dental services to the rural community, who would otherwise resort to untrained, unsterile 'help' to alleviate their pain.

The volunteers were involved in six days' clinical work during their trip, travelling for over two hours each morning and evening to reach the remote health centres where training took place. Many more people turned up for treatment each day than could be helped, but the focus for the team was on training, with a view to increasing

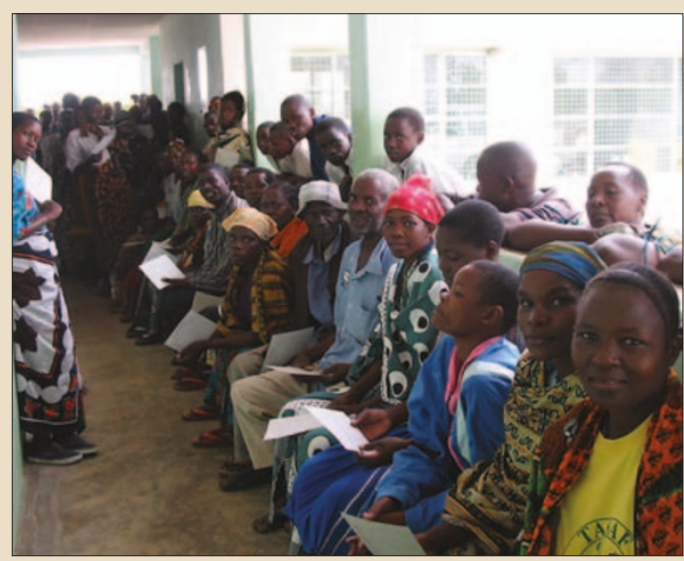

Over 120 patients turned up for treatment on the last day the capacity of the RCOs to treat their own people long after the volunteers' short visit was over.

As well as providing training for the RCOs, the charity led by Ian Wilson, also operates a nonprofit making dental clinic in Mwanza, the regional city, and a social care programme for the street community.

Dentaid and Bridge2Aid are planning further visits to Tanzania, with the next trip in May 2005. Details of how to apply can be found at Dentaid's website at www.dentaid.org.

\section{President installed}

Dr Peter Bainton was recently installed as Community Dental Services Group President at its recent annual Presidential and Scientific Meeting.

After ten years as a GDP in London, Leicestershire and then in Northamptonshire, where he became the second partner, Dr Bainton joined the Community Dental Service in Northamptonshire in 1979.

He became Senior Dental Officer (Epidemiology) in 1983 and has been BASCD survey trainer in Oxford Deanery for several years. He was operational manager for 10 years before becoming District Dental Officer and then Clinical Director. His present role is that of Assistant Clinical Director of the Salaried Primary Care Dental Services in Northamptonshire Heartlands PCTD.

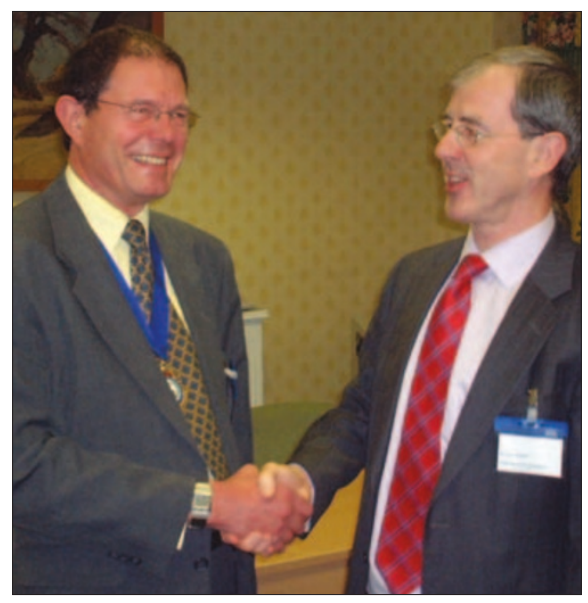

Dr Peter Bainton (left) with outgoing President Dr Gary Whittle 